GRASAS Y ACEITES 71 (3)

July-September 2020, e367

ISSN-L: 0017-3495

https://doi.org/10.3989/gya.0463191

\title{
Chemical composition, oxidative stability, and sensory properties of Boerhavia elegana Choisy (alhydwan) seed oil/peanut oil blends
}

\author{
A. Al-Farga ${ }^{\mathrm{a}, \bigotimes}$, M. Baeshen ${ }^{\mathrm{b}}$, F.M. Aqlan ${ }^{\mathrm{c}}$, A. Siddeeg ${ }^{\mathrm{d}}$, M. Afifi ${ }^{\mathrm{a}}$, \\ H.A. Ali ${ }^{\mathrm{a}}$, A. Alayafi ${ }^{\mathrm{b}}, \mathrm{S}$. Al-Dalali ${ }^{\mathrm{e}}$ and A. Alkaladi ${ }^{\mathrm{b}}$ \\ ${ }^{a}$ Department of Biochemistry, Faculty of Science, University of Jeddah, Jeddah, Saudi Arabia. \\ ${ }^{b}$ Department of Biological Sciences, Faculty of Science, University of Jeddah, Jeddah, Saudi Arabia. \\ ${ }^{c}$ Department of Chemistry, Faculty of Science, University of Jeddah, Jeddah, Saudi Arabia. \\ ${ }^{\mathrm{d}}$ Department of Food Science and Technology, Faculty of Engineering and Technology, University of Gezira, Wad Medani, Sudan. \\ ${ }^{\mathrm{e}}$ School of Food and Chemical Engineering, Beijing Technology and Business University, Beijing 100048, China. \\ ${ }^{\square}$ Corresponding author: alfergah83@gmail.com
}

Submitted: 30 April 2019; Accepted: 11 July 2019; Published online: 27 July 2020

\begin{abstract}
SUMMARY: This study investigated the effects of blending alhydwan seed oil and peanut oil as a way of enhancing the stability and chemical characteristics of plant seed oils and to discover more innovative foods of high nutraceutical value which can be used in other food production systems. Alhydwan seed oil and peanut oil blended at proportions of 10:90, 20:80, 30:70, 40:60 and 50:50 (v/v) were evaluated according to their physicochemical properties, including refractive index, relative density, saponification value, peroxide value, iodine value, free fatty acids, oxidative stability index, and tocopherol contents using various standard and published methods. At room temperature, all of the oil blends were in the liquid state. The physicochemical profiles of the blended oils showed significant decreases $(p<0.05)$ in peroxide value $\left(6.97-6.02\right.$ meq $\mathrm{O}_{2} / \mathrm{kg}$ oil), refractive index at $25^{\circ} \mathrm{C}(1.462-1.446)$, free fatty acids $(2.29-1.71 \%)$, and saponification value $(186.44-183.77 \mathrm{mg} \mathrm{KOH} / \mathrm{g})$, and increases in iodine value and relative density at $25^{\circ} \mathrm{C}(98.10-102.89$ and $0.89-0.91$, respectively), especially with an analhydwan seed oil to peanut oil ratio of 10:90. Among the fatty acids, oleic and linoleic acids were most abundant in the 50:50 and 10:90 alhydwan seed oil to peanut oil blends, respectively. Oxidative stability increased as the proportion of alhydwan oil increased. In terms of tocopherol contents $(\gamma, \delta$, and $\alpha), \gamma$-tocopherol had the highest values across all of the blended proportions, followed by $\delta$-tocopherol. The overall acceptability was good for all blends. The incorporation of alhydwan seed oil into peanut oil resulted in inexpensive, high-quality blended oil that may be useful in health food products and pharmaceuticals without compromising sensory characteristics.
\end{abstract}

KEYWORDS: Alhydwan seed; Arachis hypogaea L.; Boerhavia elegana; Fatty acids; Overall acceptability; Oxidative stability; Peanut oil; Tocopherols

RESUMEN: Composición química, estabilidad oxidativa y propiedades sensoriales de las mezclas de aceites de semillas de Boerhavia elegana Choisy (alhydwan)/aceite de maní. Este estudio investigó los efectos de mezclar aceites de semillas de alhidwan y aceites de maní como una forma de mejorar la estabilidad y las características químicas de los aceites de semillas de plantas y descubrir alimentos más innovadores de alto valor nutracéutico que pueden usarse en otros sistemas de producción de alimentos. El aceite de semilla de Alhydwan y el aceite de maní se mezclaron en proporciones: 10:90, 20:80, 30:70, 40:60 y 50:50 (v/v), respectivamente, y se evaluaron sus propiedades fisicoquímicas, incluido el índice de refracción, densidad, índice de saponificación, índice de peróxido, índice de yodo, ácidos grasos libres, estabilidad oxidativa y contenido de tocoferoles, utilizando métodos estandarizados publicados. A temperatura ambiente, todas las mezclas de aceite estaban en estado líquido. 
Los perfiles fisicoquímicos de los aceites mezclados mostraron disminuciones significativas $(\mathrm{p}<0.05)$ en el valor de peróxido $\left(6,97-6,02 \mathrm{meqO}_{2} / \mathrm{kg}\right.$ de aceite), índice de refracción a $25{ }^{\circ} \mathrm{C}(1,462-1,446)$, ácidos grasos libres (2,29-1,71\%) e índice de saponificación (186,44-183,77 mg KOH/g), y aumentos en el índice de yodo y la densidad relativa a $25^{\circ} \mathrm{C}(98,10-102,89$ y $0,89-0,91$, respectivamente), especialmente en una relación de aceite de semilla de analhidwan a aceite de maní de 10:90. Entre los ácidos grasos, los ácidos oleico y linoleico fueron los más abundantes en las mezclas de aceite de semilla de alhydwan/aceite de maní 50:50 y 10:90, respectivamente. La estabilidad oxidativa aumentó a medida que aumentó la proporción de aceite de alhidwan. En términos de contenido de tocoferoles $(\gamma, \delta$ y $\alpha$ ), el $\gamma$-tocoferol tuvo los valores más altos en todas las proporciones de las mezclas, seguido por el $\delta$-tocoferol. La aceptabilidad general fue buena para todas las mezclas. La incorporación del aceite de semilla de alhydwan al aceite de maní da como resultado mezclas económicas y de alta calidad que pueden ser útiles en productos alimenticios saludables y productos farmacéuticos sin comprometer las características sensoriales.

PALABRAS CLAVE: Aceite de cacahuete; Aceptabilidad general; Ácidos grasos; Arachis hypogaea L.; Boerhavia elegana; Estabilidad oxidativa; Semilla de Alhydwan; Tocoferoles

ORCID ID: AL-Farga A https://orcid.org/0000-0002-0233-5539, Alayafi A https://orcid.org/0000-0002-6668-5992, Baeshen M https://orcid.org/0000-0002-0235-5222, Aqlan FM https://orcid.org/0000-0001-9424-3262, Siddeeq A https:// orcid.org/0000-0002-3206-1962, Al-Dalali S https://orcid.org/0000-0002-2173-1916, Afifi M https://orcid.org/00000003-3942-4882, Ali AH https://orcid.org/0000-0003-3549-1789, Alkaladi A https://orcid.org/0000-0002-8928-4235

Citation/Cómo citar este artículo: AL-Farga A, Alayafi A, Baeshen M, Aqlan FM, Siddeeq A, Al-Dalali S, Afifi M, Ali $\mathrm{AH}$, Alkaladi A. 2020. Chemical composition, oxidative stability, and sensory properties of Boerhavia elegana Choisy (alhydwan) seed oil/peanut oil blends. Grasas Aceites 71 (3), e367. https://doi.org/10.3989/gya.0463191

Copyright: (C2020 CSIC. This is an open-access article distributed under the terms of the Creative Commons Attribution 4.0 International (CC BY 4.0) License.

\section{INTRODUCTION}

The global demand for lipids, especially those used as food and in food processing, is increasing. Thus, current sources (animal fat and vegetable oils) are becoming less sufficient (Su et al., 2014). This circumstance has been exacerbated by the proliferation of companies that manufacture toiletries, which use such lipids in their products. Therefore, it is important to explore additional sources of this important raw material. Recently, there has been increasing consumer preference for plant seed oils instead of animal-source lipids due to their proven nutritional and health benefits (Reyes-Hernandez et al., 2007). Despite this preference, the literature has demonstrated that some of these plant-based oils do not meet the standard characteristics of physicochemical properties expected by consumers, including texture and stability, when used in various product systems. One of the most common sources of these plant-based oils is the peanut (Arachis hypogaea L.) seed.

The peanut, as an oilseed crop, ranks fourth in world production, with more than 100 producing countries, including China, India, and the USA, as the top producers (around 35.5 million tonnes annually) (Pandey et al., 2012). The major components of peanut seeds include oil, protein, and carbohydrates in the ranges of 40-60, 20-40, and $10-20 \%$, respectively. Additionally, peanut seeds contain a wide range of vitamins (vitamin E, niacin, riboflavin, and thiamine) and minerals (calcium, phosphorus, magnesium, zinc, iron, and potassium)
(Pandey et al., 2012). Aside from the well-known oil seed plants (e.g., peanut, soybean, and sunflower), new sources, including alhydwan plant seed, are being explored. Alhydwan, or Boerhavia elegana Choisy, is an edible herbaceous plant from the family Nyctaginaceae. Its seed contains $11.49 \%$ crude oil, $14.60 \%$ protein, $6.12 \%$ moisture, $6.88 \%$ ash, $36.13 \%$ fiber, and $24.77 \%$ total carbohydrates (Al-Farga et al., 2015). The oil from the alhydwan seed is edible and possesses high nutritional value, with $57.8 \%$ oleic acid, $12.9 \%$ linoleic acid, and $18.6 \%$ palmitic acid, as the main fatty acids (Al-Farga et al., 2015). The total quantity of unsaturated fatty acids (oleic, linoleic, and palmitic) is $74.63 \mathrm{mg} / 100 \mathrm{~g}$. Because of this high value of unsaturated fatty acids, it has been suggested that the oil can substitute any highly unsaturated oil in the diet (Al-Farga et al., 2015). Nevertheless, compared to peanut oil, there are differences in chemical composition. Alhydwan seeds are available at a low price in many places in southern Yemen, especially during autumn (Al-Farga et al., 2014). Only a few oilseeds are currently used as conventional sources of vegetable oil in Yemen, but these oils cannot meet the current high demand; thus, there is great need to explore additional inexpensive sources to supplement the existing sources and to find novel materials for the development of new food products. In this study we investigated the effects of blending oil as a way of enhancing the stability and chemical characteristics of the blended oils. The purpose of this study was to evaluate the influence of alhydwan seed oil blending with peanut oil on physico-chemical 
composition, fatty acids, oxidative stability index, and organoleptic characteristics.

\section{MATERIALS AND METHODS}

\subsection{Materials and chemicals}

Dried B. elegana Choisy (alhydwan) seeds were supplied by a single farm in Wad Hadramout, South Yemen. The seeds were transported by air, in sealed polyethylene bags, to Jiangnan University's Food Processing and Ingredients Laboratory (Wuxi, China). Arachis hypogaea L. (peanut) seeds, in dry form, were purchased from a local supermarket in the same city in China. All chemicals were of analytical grade and were obtained from trusted suppliers.

\subsection{Oil extraction and blending}

Seeds (200 g) of B. elegana Choisy or A. hypogaea L. were milled, mixed with $1 \mathrm{~L}$ of n-hexane, and shaken for $4 \mathrm{~h}$ at $440 \mathrm{rpm}$ using a shaker $\left(\right.$ IKA $^{\circledR}$ RW 20 digital overhead stirrer, UK-plug; Staufen, Germany). The suspension was then centrifuged at $10,000 \times g$ at $4{ }^{\circ} \mathrm{C}$ for $20 \mathrm{~min}$. The supernatant was then filtered. The extraction process was repeated once with the same debris to ensure that all of the oil was completely extracted. Recovery of the oil from the n-hexane was done by evaporating the solvent using a rotary evaporator (Model N-1; Eyela, Tokyo Rikakikal, Japan). The solvent remaining in the oil was evaporated at $37^{\circ} \mathrm{C}$ for $30 \mathrm{~min}$ using a laboratory fume hood. The extracted oil was drained under a stream of nitrogen. The oils of B. elegana Choisy and $A$. hypogaea L. were then blended in proportions of 10:90, 20:80, 30:70, 40:60 and 50:50 (v/v). The blended oils were then sealed in glass tubes and stored at $4{ }^{\circ} \mathrm{C}$ in a refrigerator until analysis.

\subsection{Color parameters}

A Hunter Lab digital colorimeter (TC-PIIG system, Beijing Optical Instrument Co. Ltd., Beijing, China) was used to measure the oil blends' color and color scales such as $\mathrm{L}^{*} \mathrm{a}^{*} \mathrm{~b}^{*}$ values were recorded. A cylindrical plastic dish $(58 \mathrm{~mm}$ in diameter and $15 \mathrm{~mm}$ in depth) containing the same amount of sample was placed at the light port (50 $\mathrm{mm}$ in diameter).

\subsection{Chemical analysis of the oil blends}

Various methods stipulated by the American Oil Chemist's Society AOCS (1997) for various chemical parameters of oils were used. These included methods Ca 5a-4, Cd 8-53, Cd 3-25, and Ca 6a-40 for the determination of free fatty acids, peroxide value, saponification value, and unsaponifiable matter, respectively. Specific gravity was determined using a 10 -mL pycnometer at $25^{\circ} \mathrm{C}$. An Abbe refractometer was used at $25{ }^{\circ} \mathrm{C}$ to determine the refractive index of the oil blends. The iodine value was calculated according to the method of (Kyriakidis and Katsiloulis, 2000).

\subsection{Determination of fatty acid composition}

The composition of fatty acids was determined following the method of (He and Xia, 2007) with some modifications. First, the methylation of the crude oils was conducted to prepare fatty acid methyl esters (FAME). Then, $1 \mu \mathrm{L}$ of the FAME sample was analyzed in a gas chromatograph (Series PEG30 M) connected to a flame ionization detector. The column used was a model PEG30M column with dimensions of $30 \mathrm{~m} \times 0.32 \mathrm{~mm}$ $\times 0.50 \mu \mathrm{m}$. Nitrogen was used as the carrier gas at a flow rate of $0.8 \mathrm{~mL} / \mathrm{min}$. The oven temperature was held at $190{ }^{\circ} \mathrm{C}$ for $1 \mathrm{~min}$, then increased at a rate of $3{ }^{\circ} \mathrm{C} / \mathrm{min}$ to $230{ }^{\circ} \mathrm{C}$, and held for $10 \mathrm{~min}$. The injection port and detector were set at 240 and $250{ }^{\circ} \mathrm{C}$, respectively. Standards were run to facilitate the identification of the peaks generated from the samples. Percentage (\%) values were used to express fatty acid contents.

\subsection{Determination of oxidative stability}

The oxidative stability of the oil blends was determined with a 743 Rancimat apparatus (Metrohm Co., Basel, Switzerland). An oil blend sample of $3.6 \mathrm{~g}$ was weighed, placed in the reaction vessel, and heated at $120^{\circ} \mathrm{C}$ with an air flow of $20 \mathrm{~L} / \mathrm{h}$. As degradation of the oil progressed, volatile compounds were collected in a receiving flask containing $60 \mathrm{~mL}$ of distilled water. The conductivity of the resultant product was then measured.

\subsection{Analysis of tocol composition}

The tocol composition was determined according to the NY/T 1598-2008 method. First, a solution containing the blended oil sample ( $250 \mathrm{mg}$ ), ethanol $(25 \mathrm{~mL}), 10 \%$ ascorbic acid $(5 \mathrm{~mL})$, and $50 \% \mathrm{KOH}$ $(10 \mathrm{~mL})$ was prepared. This solution was subjected to saponification in a capped flask heated at $90{ }^{\circ} \mathrm{C}$ for $1 \mathrm{~h}$ in a water bath. Then, the solution was cooled and $100 \mathrm{~mL}$ of distilled water were added. After mixing thoroughly, $50 \mathrm{~mL}$ of diethyl ether were added to extract the solution. The upper layer was scooped off and washed to a neutral $\mathrm{pH}$ with distilled water. After separation, the organic layer was dried over $\mathrm{Na}_{2} \mathrm{SO}_{4}$. The dry matter was then dissolved in $2 \mathrm{~mL}$ of ethanol and centrifuged at $5000 \mathrm{rpm}$ for $5 \mathrm{~min}$. The upper layer of the supernatant $(10 \mu \mathrm{L})$ was analyzed with a high performance liquid chromatography (HPLC) system (Waters Corp., Milford, MA, USA) with a Spherisorb silica column $(250 \mathrm{~mm} \times 4.6 \mathrm{~mm}, 5 \mu \mathrm{m})$ operating at $30{ }^{\circ} \mathrm{C}$ with 
methanol/water $(98: 2, \mathrm{v} / \mathrm{v})$ as the mobile phase flowing at a rate of $1.0 \mathrm{~mL} / \mathrm{min}$. The detector used was a model 2996 PAD (Waters Corp.) with the wavelength set at $290 \mathrm{~nm}$. Tocol was calculated as $\mathrm{mg} / \mathrm{kg}$ oil.

\subsection{Sensory evaluation}

The acceptability of the B. elegana Choisy and $A$. hypogaea $\mathrm{L}$. oil blends was assessed by a trained panel of 10 members, using the conventional 9-point hedonic scale (ranging from 1 [extremely bad] to 9 [excellent]). The measurement attributes included crust color, crumb color, crumb texture, flavor, taste, and overall acceptability.

\subsection{Statistical analysis}

All the data were expressed as the mean \pm standard deviation. A statistical analysis was performed using one-way analysis of variance. Comparisons between pairs of means were made using Duncan's multiple range test, with statistical significance at $p$ $\leq 0.05$ (Snedecor and Cochran, 1980). The statistical analysis was conducted with the SAS program (SAS,2002).

\section{RESULTS AND DISCUSSIONS}

\subsection{Physiochemical profiles of the oil blends}

The physiochemical profiles of the oil blends are presented in Table 1. The results show that all of the blended samples were in the liquid state at room temperature and that no differences in appearance could be observed among them. However, significant differences $(p<0.05)$ were observed across all blend ratios in all of the remaining physicochemical parameters. The addition of alhydwan seed oil to peanut oil decreased the peroxide value (meq $\mathrm{O}_{2} / \mathrm{kg}$ oil) of the blended oil significantly from 6.97 at a blend ratio of 10:90 to 6.02 at a blend ratio of 50:50. Similar trends between the same two blend proportions were observed for the refractive index at $25{ }^{\circ} \mathrm{C}(1.462$ to 1.446$)$, free fatty acids (2.29 to $1.71 \%$ ), and saponification value (186.44 to $183.77 \mathrm{mg} \mathrm{KOH} / \mathrm{g}$ ). Nevertheless, the addition of alhydwan seed oil to peanut oil increased the iodine value and relative density at $25{ }^{\circ} \mathrm{C}$ from 98.10 to 102.89 and from 0.89 to 0.91 for the same two blend proportions, respectively.

There is a positive relationship between the saponification value of oil and the solubility of a soap product made from that oil (Alyas et al., 2006). The reduction in saponification value with increases in the proportion of alhydwan oil in the blends may indicate that the resultant soap would have lower solubility. That is, these oils would be better used for products other than soap. The peroxide value is defined as the weight of active oxygen in $1 \mathrm{~g}$ of oil

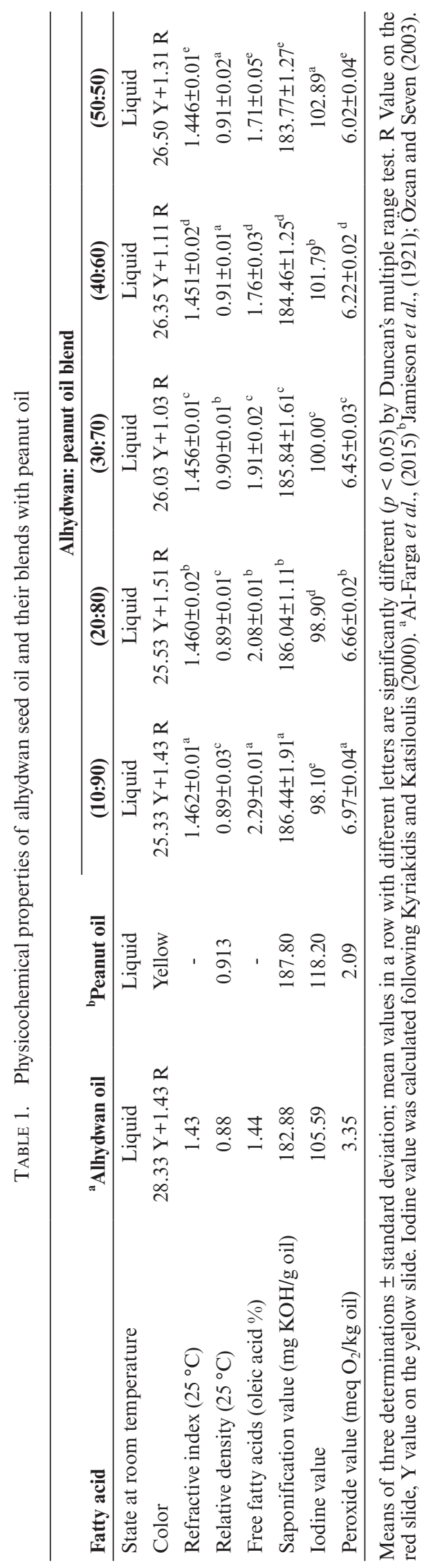


(Pandurangan et al., 2014). It indicates that the oil has started to degrade, a situation that is common in unsaturated oils (Al-Farga et al., 2015). The reduction in peroxide value observed for the oil blends signifies that the addition of alhydwan oil to peanut oil makes the latter slightly more resistant to degradation. According to the method developed by (Kyriakidis and Katsiloulis, 2000) the iodine values of the blended oils ranged from 98.10 to 102.89 . These high values may be attributed to the observed high unsaturated fatty acid contents. This result indicates that the seed oil has good edibility and drying qualities (Eromosele et al., 1997). Based on the chemical compositions of the blended oils, there were no negative effects caused by the addition of alhydwan seed oil.

\subsection{Fatty acid composition}

The fatty acid compositions of the alhydwan seed, peanut, and blended oils are recorded in Table 2. In total, 10 fatty acids were identified, of which 5 were unsaturated. Oleic acid and linoleic acid were more abundant in all the blended oil samples. The 50:50 and 10:90 (alhydwan-peanut) oil blends had the highest oleic acid and linoleic acid contents, respectively. Table 2 also shows that the blended oils were significantly enriched with unsaturated fatty acids.

The results of the fatty acid determination showed high contents of oleic acid in the pure alhydwan seed oil. This indicates that alhydwan seed oil has potential health benefits for patients with arteriosclerosis and hypertension (Oomah et al., 2000). The results further demonstrate that incorporating alhydwan oil into peanut oil may increase the monounsaturated fatty acid (MUFA) content of the latter, which would contribute to reductions in lowdensity lipoprotein cholesterol in the human body (Wahida, 2005). The addition of alhydwan seed oil to peanut oil has positive effects on the content of fatty acids and potential health benefits.

\subsection{Oxidative stability of the blended oils}

The results from the Rancimat test are presented in Table 3. Stability is expressed as the oxidation induction time (h). The oxidative stability index values for pure alhydwan seed oil and pure peanut oil

TABLE 3. Oxidative stability index (h) of alhydwan seed oil and their blends with peanut oil

\begin{tabular}{lc}
\hline Blend & Oxidative stability index (h) \\
\hline Alhydwan oil & $16.82 \pm 0.09^{\mathrm{a}}$ \\
Peanut oil & $2.78 \pm 0.07^{\mathrm{g}}$ \\
Alhydwan oil: peanut oil (10:90) & $3.22 \pm 0.03^{\mathrm{f}}$ \\
Alhydwan oil: peanut oil (20:80) & $3.91 \pm 0.01^{\mathrm{e}}$ \\
Alhydwan oil: peanut oil (30:70) & $4.62 \pm 0.01^{\mathrm{d}}$ \\
Alhydwan oil: peanut oil (40:60) & $5.02 \pm 0.01^{\mathrm{c}}$ \\
Alhydwan oil: peanut oil (50:50) & $5.34 \pm 0.01^{\mathrm{b}}$
\end{tabular}

Means of three determinations \pm standard deviation; mean values in a column with different letters are significantly different $(p<0.05)$ by Duncan's multiple range test.

TABLE 2. Fatty acid (\%) composition of alhydwan seed oil, peanut oil and their blends

\begin{tabular}{|c|c|c|c|c|c|c|c|}
\hline \multirow[b]{2}{*}{ Fatty acid } & \multirow[b]{2}{*}{ Alhydwan oil } & \multirow[b]{2}{*}{ Peanut oil } & \multicolumn{5}{|c|}{ Alhydwan: peanut oil blend } \\
\hline & & & $(10: 90)$ & $(20: 80)$ & $(30: 70)$ & $(40: 60)$ & $(50: 50)$ \\
\hline Myristic acid (C14:0) & $0.2 \pm 0.01^{\mathrm{a}}$ & $0.04 \pm 0.01^{\mathrm{c}}$ & $0.02 \pm 0.01^{\mathrm{e}}$ & $0.02 \pm 0.01^{\mathrm{e}}$ & $0.05 \pm 0.01^{\mathrm{b}}$ & $0.03 \pm 0.01^{\mathrm{d}}$ & $0.03 \pm 0.01^{\mathrm{d}}$ \\
\hline Palmitic acid (C16:0) & $18.6 \pm 0.03^{\mathrm{a}}$ & $11.17 \pm 0.02^{\mathrm{g}}$ & $11.29 \pm 0.05^{\mathrm{f}}$ & $12.67 \pm 0.01^{\mathrm{e}}$ & $13.17 \pm 0.05^{\mathrm{d}}$ & $14.07 \pm 0.05^{\mathrm{c}}$ & $14.57 \pm 0.02^{\mathrm{b}}$ \\
\hline Stearic acid (C18:0) & $2.1 \pm 0.06^{\mathrm{g}}$ & $4.75 \pm 0.02^{\mathrm{a}}$ & $4.61 \pm 0.02^{\mathrm{b}}$ & $4.52 \pm 0.05^{\mathrm{c}}$ & $4.05 \pm 0.02^{\mathrm{d}}$ & $3.91 \pm 0.01^{\mathrm{e}}$ & $3.75 \pm 0.05^{\mathrm{f}}$ \\
\hline Arachidic acid (C20:0) & $1.3 \pm 0.04^{\mathrm{f}}$ & $1.59 \pm 0.01^{\mathrm{a}}$ & $1.59 \pm 0.01^{\mathrm{a}}$ & $1.50 \pm 0.01^{\mathrm{b}}$ & $1.39 \pm 0.01^{\mathrm{d}}$ & $1.31 \pm 0.05^{\mathrm{e}}$ & $1.41 \pm 0.01^{\mathrm{c}}$ \\
\hline Docosanoic acid (C22:0) & ND & $2.32 \pm 0.02^{\mathrm{a}}$ & $2.14 \pm 0.02^{\mathrm{b}}$ & $2.01 \pm 0.01^{\mathrm{c}}$ & $1.60 \pm 0.02^{\mathrm{d}}$ & $1.60 \pm 0.02^{\mathrm{d}}$ & $1.60 \pm 0.02^{\mathrm{d}}$ \\
\hline Palmitoleic acid (C16:1) & $0.16 \pm 0.02^{\mathrm{a}}$ & $0.07 \pm 0.01^{\mathrm{e}}$ & $0.07 \pm 0.01^{\mathrm{e}}$ & $0.09 \pm 0.05^{\mathrm{d}}$ & $0.10 \pm 0.01^{\mathrm{c}}$ & $0.12 \pm 0.03^{\mathrm{b}}$ & $0.12 \pm 0.05^{\mathrm{b}}$ \\
\hline Oleic acid (C18:1) & $57.8 \pm 0.4^{\mathrm{a}}$ & $43.54 \pm 0.02^{\mathrm{g}}$ & $43.90 \pm 0.05^{\mathrm{f}}$ & $44.54 \pm 0.06^{\mathrm{e}}$ & $45.54 \pm 0.02^{\mathrm{d}}$ & $47.19 \pm 0.05^{\mathrm{c}}$ & $49.54 \pm 0.05^{\mathrm{b}}$ \\
\hline Linoleic acid (C18:2) & $12.9 \pm 0.09^{\mathrm{g}}$ & $35.90 \pm 0.02^{\mathrm{a}}$ & $34.98 \pm 0.01^{\mathrm{b}}$ & $33.13 \pm 0.01^{\mathrm{c}}$ & $29.83 \pm 0.01^{\mathrm{d}}$ & $27.08 \pm 0.04^{\mathrm{e}}$ & $25.90 \pm 0.05^{\mathrm{f}}$ \\
\hline Linolenic acid (C18:3) & $2.3 \pm 0.05^{\mathrm{a}}$ & $0.04 \pm 0.01^{\mathrm{f}}$ & $0.09 \pm 0.01^{\mathrm{e}}$ & $0.28 \pm 0.01^{\mathrm{d}}$ & $0.62 \pm 0.01^{\mathrm{c}}$ & $1.1 \pm 0.04^{\mathrm{b}}$ & $1.1 \pm 0.04^{\mathrm{b}}$ \\
\hline Eicosenoic acid (C20:1) & $1.5 \pm 0.03^{\mathrm{a}}$ & $0.57 \pm 0.01^{\mathrm{f}}$ & $0.59 \pm 0.01^{\mathrm{e}}$ & $0.70 \pm 0.01^{\mathrm{d}}$ & $0.80 \pm 0.01^{\mathrm{c}}$ & $0.80 \pm 0.01^{\mathrm{c}}$ & $0.97 \pm 0.01^{\mathrm{b}}$ \\
\hline$\Sigma \mathrm{SFA}$ & $22.2^{\mathrm{a}}$ & $19.87^{\mathrm{b}}$ & $17.51^{\mathrm{g}}$ & $18.71^{\mathrm{e}}$ & $18.66^{\mathrm{f}}$ & $19.32^{\mathrm{d}}$ & $19.76^{\mathrm{c}}$ \\
\hline$\Sigma$ UEA & $74.6^{\mathrm{g}}$ & $80.11^{\mathrm{a}}$ & $79.56^{\mathrm{b}}$ & $78.65^{\mathrm{c}}$ & $76.79^{\mathrm{e}}$ & $76.17^{\mathrm{f}}$ & $77.51^{\mathrm{d}}$ \\
\hline$\Sigma$ MUFA & $59.4^{\mathrm{a}}$ & $44.17^{\mathrm{f}}$ & $44.96^{\mathrm{e}}$ & $45.50^{\mathrm{d}}$ & $46.50^{\mathrm{c}}$ & $48.59^{\mathrm{b}}$ & $50,63^{\mathrm{b}}$ \\
\hline ¿PUFA & $15.2^{\mathrm{g}}$ & $35.93^{\mathrm{a}}$ & $35.07^{\mathrm{b}}$ & $33.41^{\mathrm{c}}$ & $30.45^{\mathrm{d}}$ & $28.18^{\mathrm{e}}$ & $27.1^{\mathrm{f}}$ \\
\hline
\end{tabular}

Means of three determinations \pm standard deviation; mean values in a row with different letters are significantly different $(p<0.05)$ by Duncan's multiple range test. SFA = saturated fatty acids, MUFA = monounsaturated fatty acids, PUFA = polyunsaturated fatty acids, UFA = unsaturated fatty acids, ND = not detected. 
were 16.82 and $2.78 \mathrm{~h}$, respectively. Compared to the value for pure peanut oil, the blending of the two oils increased the oxidative stability as the proportion of alhydwan oil was increased.

The oxidative stability of alhydwan seed oil was found to be similar to the stability obtained by (Mariod and Matthäus, 2007) in Cucumis melo var. agrestis oil. The higher stability values shown by the blended samples in this study may be attributable to the high content of MUFAs which contain single double bonds in their chain and have a slower rate of oxidation associated with their corresponding esters than polyunsaturated esters (da Silva Araujo et al.,2014). On the other hand, this value may be justified by the fact that the oil was crude. A linear regression based on the ratio of linoleic acid and the contents of tocopherols and phenols in virgin olive oil and a good correlation with oxidative stability measured by the Rancimat test have been reported (Aparicio et al.,1999).

\subsection{Tocopherol content}

Table 4 presents the tocopherol contents $(\gamma, \delta$, and $\alpha$ ) of the oil samples. $\beta$-Tocopherol was not detected. $\gamma$-Tocopherol had the highest proportions in all of the blends $(54.25,64.64,66.59,67.07$, and $66.59 \%$ in the 10:90, 20:80, 30:70, 40:60, and 50:50 alhydwan-peanut blends, respectively) followed by $\delta$-tocopherol $(29.10,32.85,31.22,30.87$, and $31.43 \%$, respectively), the incorporation of alhydwan seed oil into peanut oil improved the quality characteristics of the high-quality blended oils, because alhydwan oil is a rich source of tocopherols (AL-Farga et al.,2015). The total tocopherol content in all of the blended oils $(580-719 \mathrm{mg} / \mathrm{kg}$ ) was close to the content obtained by (Azhari and Wenshui, 2015) in a blend of 5\% Cucumis melo var. tibish oil and 95\% peanut oil, but lower than those of 50:50 coconut oil-rice bran oil, 50:50 coconut oil-palm oil, and 20:80 coconut oil-sunflower oil blends (Bhatnagar et al., 2009). It has been reported that $\alpha$-tocopherol is good for human nutrition due to its higher biological activity than other tocopherols (Fatnassi et al., 2009). Thus, the addition of alhydwan seed oil to peanut oil can be considered a good method to improve the quality characteristics and oxidative stability of the oils.

\subsection{Sensory evaluation}

The sensory characteristics (color, flavor, turbidity, taste, and overall acceptability) of the oil blends were recorded and are shown in Table 5 . The results in Table 6 show that all of the blended oils are generally acceptable for consumption, with no significant differences among them. Thus, additional studies pertaining to the utilization of alhydwan seed oil and peanut oil blends in other food products should be carried out.

\section{CONCLUSION}

This study developed a new oil product by blending alhydwan seed oil and peanut oil in specific proportions. The quality parameters assessed indicate that the blended oils are suitable for use in the processing of healthy food products. Considering the lower cost of the raw materials in some countries, the findings of this study should also help the oil industry manufacture economically viable oils for various purposes, including use in pharmaceuticals.

TABLE 5. Organoleptic properties of alhydwan seed/peanut oil blend

\begin{tabular}{|c|c|c|c|c|c|}
\hline \multirow[b]{2}{*}{ Parameter } & \multicolumn{5}{|c|}{ Alhydwan oil: peanut oil } \\
\hline & $(10: 90)$ & $(20: 80)$ & $(30: 70)$ & $(40: 60)$ & $(50: 50)$ \\
\hline Yellow color & $7.00^{\mathrm{a}}$ & $7.10^{\mathrm{a}}$ & $7.10^{\mathrm{a}}$ & $7.10^{\mathrm{a}}$ & $7.00^{\mathrm{a}}$ \\
\hline Flavor & $7.60^{\mathrm{a}}$ & $7.60^{\mathrm{a}}$ & $7.70^{\mathrm{a}}$ & $7.70^{\mathrm{a}}$ & $7.70^{\mathrm{a}}$ \\
\hline Turbidity & $7.10^{\mathrm{a}}$ & $7.10^{\mathrm{a}}$ & $7.00^{\mathrm{a}}$ & $7.00^{\mathrm{a}}$ & $7.10^{\mathrm{a}}$ \\
\hline Taste & $7.50^{\mathrm{a}}$ & $7.60^{\mathrm{a}}$ & $7.50^{\mathrm{a}}$ & $7.60^{\mathrm{a}}$ & $7.60^{\mathrm{a}}$ \\
\hline Overall & $7.30^{\mathrm{a}}$ & $7.35^{\mathrm{a}}$ & $7.33^{\mathrm{a}}$ & $7.35^{\mathrm{a}}$ & $7.35^{\mathrm{a}}$ \\
\hline
\end{tabular}

Means of three determinations \pm standard deviation; mean values in a row with different letters are significantly different $(p<0.05)$ by Duncan's multiple range test.

TABLE 4. Tocopherol contents ( $\mathrm{mg} / \mathrm{kg}$ oil) of alhydwan seed oil, peanut oil and their blends

\begin{tabular}{llllllll}
\hline & & & \multicolumn{4}{c}{ Alhydwan:peanut oil } \\
\cline { 3 - 7 } Tocopherol & \multicolumn{1}{c}{ Alhydwan oil } & \multicolumn{1}{c}{ Peanut oil } & \multicolumn{1}{c}{$(\mathbf{1 0 : 9 0 )}$} & \multicolumn{1}{c}{$\mathbf{( 2 0 : 8 0 )}$} & \multicolumn{1}{c}{$\mathbf{( 3 0 : 7 0 )}$} & $\mathbf{( 4 0 : 6 0 )}$ & $\mathbf{( 5 0 : 5 0 )}$ \\
\hline Total tocopherol & $82.9 \pm 0.09^{\mathrm{g}}$ & $511.85^{\mathrm{f}}$ & $580.63^{\mathrm{d}}$ & $538.67^{\mathrm{e}}$ & $601.47^{\mathrm{c}}$ & $683.47^{\mathrm{b}}$ & $719.37^{\mathrm{a}}$ \\
$\alpha$-Tocopherol & $9.2 \pm 0.09^{\mathrm{g}}$ & $24.44 \pm 0.02^{\mathrm{a}}$ & $11.29 \pm 0.05^{\mathrm{f}}$ & $12.67 \pm 0.01^{\mathrm{e}}$ & $13.17 \pm 0.05^{\mathrm{d}}$ & $14.07 \pm 0.05^{\mathrm{c}}$ & $14.57 \pm 0.02^{\mathrm{b}}$ \\
$\delta$-Tocopherol & $20.2 \pm 0.11^{\mathrm{g}}$ & $195.80 \pm 0.06^{\mathrm{c}}$ & $169.00 \pm 0.03^{\mathrm{f}}$ & $177.80 \pm 0.01^{\mathrm{e}}$ & $187.80 \pm 0.01^{\mathrm{d}}$ & $211.00 \pm 0.13^{\mathrm{b}}$ & $226.00 \pm 0.13^{\mathrm{a}}$ \\
$\gamma$-Tocopherol & $53.3 \pm 0.06^{\mathrm{g}}$ & $291.60 \pm 0.03^{\mathrm{f}}$ & $315.00 \pm 0.81^{\mathrm{e}}$ & $348.20 \pm 0.02^{\mathrm{d}}$ & $400.50 \pm 0.01^{\mathrm{c}}$ & $458.40 \pm 0.03^{\mathrm{b}}$ & $478.80 \pm 0.02^{\mathrm{a}}$ \\
\hline
\end{tabular}

Means of three determinations \pm standard deviation; mean values in a row with different letters are significantly different $(p<0.05)$ by Duncan's multiple range test. 


\section{ACKNOWLEDGMENT}

The authors acknowledge financial assistance from the Priority Academic Program of Jiangsu Higher Education Institutions (Wuxi, Jiangsu Province, PR China) and thank the Research Center of Functional Ingredients and Health Foods Laboratory for allowing access to their laboratory. The authors also thank the staff and students at the Center for their help in bringing the raw materials into China.

\section{Disclosure of interests}

The authors declare that they have no conflicts of interest related to any portion of the study or the preparation of the manuscript.

The English in this document was checked by at least two professional editors, both native speakers of English. For a certificate, please see: http://www. textcheck.com/certificate/ZrPLqp

\section{REFERENCES}

Al-Farga A, Zhang H, Azhari S. 2014. In Vitro Antioxidant Activity and Total Phenolic and Flavonoid Contents of Alhydwan (Boerhavia elegana Choisy) Seeds. J. Food Nutr. Res. 2, 215-220. https://doi.org/10.12691/jfnr-2-5-2

Al-Farga A, Zhang H, Azhari S, Chamba MVM, Nabil QA. 2015. Physicochemical properties, phenolic acids and volatile compounds of oil extracted from dry alhydwan (Boerhavia elegana Choisy) seeds. Grasas Aceites 66 (3) e090. https://doi.org/10.3989/gya.0944142

Alyas SA, Abdulah A, Idris NA. 2006. Oil Palm Res. (Special Issue), pp. 99-102

AOCS. 1997. Official Methods and Recommended Practices of the American Oil Chemists Society, $5^{\text {th }}$ ed. AOCS Press, Champaign, USA.

Aparicio R, Roda L, Albi MA, Gutierrez F. 1999. Effect of various compounds on virgin olive oil stability measured by Rancimat. J. Agric. Food Chem. 47, 4150-4155. https://doi. org/10.1021/jf9812230

Azhari S, Wenshui X. 2015. Oxidative stability, chemical composition and organoleptic properties of seinat (Cucumis melo var. tibish) seed oil blends with peanut oil from China. J. Food Sci. Technol. 12, 8172-8179. https://doi. org/10.1007/s13197-015-1889-x

Eromosele IC, Eromosele CO, Innazo P, Njerim P. 1997. Studies on some seeds and seed oils. Bioresource
Technol. 64, (3) 245-247. https://doi.org/10.1016/ S0960-8524(97)00163-6

Fatnassi S, Nehdi I, Zarrouk H. 2009. Chemical composition and profile characteristics of Osage orange Maclurapomifera (Rafin.) Schneider seed and seed oil. Ind. Crops Prod. 29, 1-8. https://doi.org/10.1016/j.indcrop.2008.04.013

He ZY, Xia WS. 2007. Nutritional composition of the kernels from Canarium album L. Food Chem. 102, 808-811. https:// doi.org/10.1016/j.foodchem.2006.06.017

Jamieson GS, Baughman WF, Brauns DH. 1921. The chemical composition of peanut oil. J. Am. Oil Chem. Soc. 43, $1372-1381$.

Kyriakidis NB, Katsiloulis T. 2000. Calculation of iodine value from measurements of fatty acid methyl esters of some oils: comparison with the relevant American Oil Chemists Society Method. J. Am. Oil Chem. Soc. 77, 1235-1238. https://doi.org/10.1007/s11746-000-0193-3

Mariod AA, Matthäus B. 2007. Fatty acids, tocopherols, sterols, phenolic profiles and oxidative stability of Cucumis melo var. agrestis oil. J. Food Lipids 15, 56-67. https://doi. org/10.1111/j.1745-4522.2007.00102.x

Oomah BD, Ladet S, Godfrey DV, Liang J, Girard B. 2000. Characteristics of raspberry (Rubusidaeus L.) seed oil. Food Chem. 69, 187-193. https://doi.org/10.1016/ S0308-8146(99)00260-5

Özcan M, Seven S. 2003. Physical and chemical analyses and fatty acid composition of peanut, peanut oil and peanut butter from ÇOM and NC-7 cultivars. Grasas Aceites $\mathbf{5 4}$ (1), 12-18.

Pandey MK. 2012. Advances in Arachis genomics for peanut improvement. Biotechnol. Adv. 30, 639-651. https://doi. org/10.1016/j.biotechadv.2011.11.001

Pandurangan MK, Murugesan S, Gajivaradhan P. 2014. Physicochemical properties of groundnut oil and their blends with other vegetable oils. J. Chem. Pharm. Res. 6, 60-66.

Reyes-Hernandez J, Dibildox-Alvarado E, Charo-Alonso M, Toro-Vazquez J. 2007. J. Am. Oil Chem. Soc. 84, 1081-1093.

SAS. 2002. Statistical analysis system. User manual SAS/STAT 9 version. SAS Institute Inc., NC, USA.

Silva Araujo F da, Araujo IC, Costa ICG, Rodarte de Moura CV, Chaves MH, Araujo ECE. 2014. Study of degumming process and evaluation of oxidative stability of methyl and ethyl biodiesel of Jatropha curcas L. oil from three different Brazilian states. Renewable Energy 71, 495-501. https://doi.org/10.1016/j.renene.2014.06.001

Snedecor GW, Cochran WG. 1980. Statistical Methods. 7Ed. Iowa State University Press, Ames, Iowa.

Su MH, Shih MC, Lin KH. 2014. Chemical composition of seed oils in native Taiwanese Camellia species. Food Chem. 156, 369-373. https://doi.org/10.1016/j.foodchem. 2014.02.016

Wahida Karmally RD. 2005. Balancing unsaturated fatty acids: what's the evidence for cholesterol lowering. J. Am. Diet Assoc. 105, 1068-1070. 